\title{
Natural radionuclides in plants, soils and sediments affected by U-rich coal mining activities in Brazil
}

\author{
Juliana Aparecida Galhardi a, *, Rafael García-Tenorio ${ }^{\mathrm{b}}$, Daniel Marcos Bonotto ${ }^{\mathrm{a}}$, \\ Inmaculada Díaz Francés ${ }^{b}$, João Gabriel Motta ${ }^{c}$ \\ a Departamento de Petrologia e Metalogenia, Universidade Estadual Paulista (UNESP), Campus de Rio Claro, Av. 24-A No.1515, CEP 13506-900, Rio Claro, \\ São Paulo, Brazil \\ ${ }^{\mathrm{b}}$ Departamento de Física Aplicada II, Universidad de Sevilla, Av. Reina Mercedes, 2, 41012, Seville, Spain \\ ${ }^{\mathrm{c}}$ Instituto de Geociências, Universidade de Campinas, R. João P. Calógeras, 51, CEP 13083-870, Campinas, São Paulo, Brazil
}

\section{A R T I C L E I N F O}

\section{Article history:}

Received 3 January 2017

Received in revised form

1 May 2017

Accepted 1 June 2017

Available online 9 June 2017

\section{Keywords:}

Biomonitoring

Coal mining

Uranium

Thorium

Polonium

\begin{abstract}
A B S T R A C T
Mining activities can increase the mobility of metals by accelerating the dissolution and leaching of minerals from the rocks and tailing piles to the environment and, consequently, their availability for plants and subsequent transfer to the food chain. The weathering of minerals and the disposal of coal waste in tailing piles can accelerate the generation of acid mine drainage (AMD), which is responsible for the higher dissolution of metals in mining areas. In this context, the behavior of $\mathrm{U}$, Th and $\mathrm{K}$ in soils and sediment, and the transfer factor (TF) of ${ }^{238} \mathrm{U},{ }^{234} \mathrm{U}$ and ${ }^{210} \mathrm{Po}$ for soybean, wheat, pine and eucalyptus cultivated around a coal mine in southern Brazil was evaluated. Alpha and gamma spectrometry were used for the measurements of the activity concentration of the radioelements. ${ }^{210} \mathrm{Po}$ was the radionuclide that is most accumulated in the plants, especially in the leaves. When comparing the plant species, pine showed the highest TF values for ${ }^{234} \mathrm{U}(0.311 \pm 0.420)$ for leaves, while eucalyptus showed the highest TF for ${ }^{238} \mathrm{U}(0.344 \pm 0.414)$ for leaves. In general, TF were higher for the leaves of soybean and wheat when compared to the grains, and grains of wheat showed higher TF for ${ }^{210} \mathrm{Po}$ and ${ }^{238} \mathrm{U}$ than grains of soybean. Deviations from the natural $U$ isotopic ratio were recorded at all investigated areas, indicating possible industrial and mining sources of $U$ for the vegetables. A safety assessment of transport routes and accumulation of radionuclides in soils with a potential for cultivation is important, mainly in tropical areas contaminated with solid waste and effluents from mines and industry.
\end{abstract}

() 2017 Elsevier Ltd. All rights reserved.

\section{Introduction}

Natural radioelements are part of the chemistry of soils and waters, resulting in radiological dose for living organisms. Mining activities contribute to increase this dose as they accelerate the leaching of elements and minerals from rocks to the environment (USEPA, 1995; Baik et al., 2003; Flues et al., 2006; Fungaro and Izidoro, 2006).

In coal mines, the disposal of waste in tailing piles and ore exposure to weathering conditions can accelerate the formation of acid mine drainage (AMD). This acid effluent accelerates the leaching of toxic elements in coal mining areas and is generated when sulfide minerals (e.g. pyrite, $\mathrm{Fe}_{2} \mathrm{~S}$ ) are oxidized due to

\footnotetext{
* Corresponding author.

E-mail address: julianagalhardi@yahoo.com.br (J.A. Galhardi).
}

exposition to atmospheric oxygen, promoting a reduction of the $\mathrm{pH}$ level and the solubilization of metals into the aqueous medium (Berghorn and Hunzeker, 2001; Mkandawire, 2013). In addition to the release of radionuclides by discharge by tailings seepage waters, emissions of radionuclides by dry or wet deposition of resuspended radioactive material from tailings piles may lead to elevated levels in the nearby soil, where they can be adsorbed, retained and taken up by plants (Planinsek et al., 2016). Particulate matter and radionuclides released to the atmosphere from coalfired power plants can also return to the ground as wet or dry deposition, contributing to the radiation dose exposure (Papp et al., 2002).

The occurrence of uranium (U) in coal has been investigated for more than a half of a century and the major concern is related to the use of coal for electricity generation (Baxter, 1993; Arbuzov et al., 2012). In addition to common contaminants related to sulfur- and metal-bearing minerals, the particulate matter and effluents 
generated during the coal fired-power plant and coal mining activities may contain ${ }^{226} \mathrm{Ra},{ }^{210} \mathrm{~Pb}$ and ${ }^{238} \mathrm{U}$ (UNSCEAR, 2010). As example, coal contains approximately $12-24 \mathrm{~Bq} \mathrm{~kg}^{-1}$ of ${ }^{238} \mathrm{U}$ and 12-17 $\mathrm{Bq} \mathrm{kg}^{-1}$ of ${ }^{232} \mathrm{Th}$ (UNSCEAR, 2010).

In solutions, adsorption is an important mechanism that controls U activity concentration (Prikryl et al., 2001). The chemical behavior of $U$ depends on several characteristics, e.g. pH, Eh, concentration and type of organic and inorganic ligands, presence of chelating agents, speciation, mixing rate and movement of the water, reactions of complexation, precipitation, adsorption and desorption. However, since to obtain and interpret all this information is complex, $\mathrm{pH}$ and $\mathrm{Eh}$ are the most common parameters used in investigations about $U$ mobilization processes and explain most variation of concentration of $U$ in waters (Langmuir, 1978; Giblin et al., 1981).

In this context, to evaluate radiological impacts due to extraction, processing and burning of coal, some plants have been used for the assessment of soil contamination. The most commonly index used to estimate the radionuclides transport and their accumulation in vegetables is the transfer factor (TF), defined as the ratio between the concentration of the element in plants $\left(A_{m}=\right.$ activity concentration of the radionuclide in plant dry matter) and in the soil ( $A_{s}=$ activity concentration of the investigated element in dry soil). This is alternatively known as the concentration ratio (CR). The TF describes the concentration of the element that can be absorbed by a plant from its substrate under equilibrium conditions, assuming that the accumulation is directly proportional to the concentration of the element in the soil (Sheppard and Sheppard, 1985).

An understanding of the mobility of natural radionuclides in soils and their TFs to different plants requires knowing their interactions with soils (Shtangeeva, 2010). The uptake of trace elements by biota can be affected by the electrical conductivity (EC), cation exchange capacity (CEC), total organic carbon (TOC), nutrients, mineralogy and climate, in addition to (bio)chemical processes such as complexation, precipitation and redox reactions (Sohlenius et al., 2013; Gupta et al., 2014; Zhao et al., 2016). However, in about $50 \%$ of the investigations focusing on the TF, these characteristics were not considered (Vandenhove et al., 2009), which limits our understanding on the metal uptake by the biota. An assessment of the radionuclide distributions in the soil-plant system may be also rather complicated because there is little information related to the rate of radionuclides uptake and storage by different parts of plant species (Shtangeeva, 2010).

Until the present, most of the studies of TF were in temperate areas, where climatic conditions, weathering processes, nutrients cycling and metal uptake by living organisms differ significantly from those in tropical areas (IAEA, 2010). Few systematic investigations have been done in cultivated tropical soils affected by coal mining, especially in Brazil. According to the Food and Agricultural Organization (FAO, 2012), Brazil is the 10th largest vegetable producer in the world and the 2 nd largest soybean producer. Paraná State is the 2nd largest producer of this legume in Brazil, and also has the 3rd largest coal reserve in the country that is associated with a U deposit.

Previous studies indicated high levels of radionuclides and trace elements in soils from Southern Brazil associated with AMD (Flues et al., 2006; Campaner et al., 2014). This is the case of Figueira city, Paraná State, Brazil, where the coal mined there exhibits high content of pyrite (MINEROPAR, 2001) that may accelerate the environmental problems associated with AMD generation. The coal has also elevated contents of $U$ and thorium (Th) (Fernandes et al., 1997). Flues et al. (2006) reported ${ }^{238} U$ and ${ }^{232} \mathrm{Th}$ concentrations ranging from $813 \mathrm{~Bq} \mathrm{~kg}^{-1}$ to $2609 \mathrm{~Bq} \mathrm{~kg}^{-1}$ and from $22 \mathrm{~Bq} \mathrm{~kg}^{-1}$ to $40 \mathrm{~Bq} \mathrm{~kg}^{-1}$, respectively, in coal sampled in that area.
Some researchers in Brazil investigated the absorption of radionuclides by plants from soil (Vasconcellos et al., 1987; Santos et al., 1993, 2002; Lauria et al., 1994; Mazzilli et al., 2012), but no investigation was performed in areas affected by coal mining. Radionuclide analysis in vegetables cropped near coal mining areas in southern Brazil, especially for those plants used for human consumption, could improve the radiological risk assessment. In this context, this paper aims 1 ) to evaluate the influence of a coalfired power plant and coal mining activities on the characteristics of nearby soils and sediments and 2) to investigate the uptake of radionuclides by plants (soybean and wheat - leaves and grains, pine and eucalyptus - leaves and bark) in an impacted tropical environment.

\section{Material and methods}

\subsection{General features of the study area}

The city of Figueira is located in the northeastern of Paraná State in Brazil (Fig. 1). The climate is divided into a rainy season (October to March) and a dry season (April to September). The predominant soils are shallow, acidic, dystrophic, with a poor drainage and a high saturation of exchangeable aluminum (Morrone and Daemon, 1985). The soils around the mining area are used for agricultural activities. Major crops in the area are soybean and corn, for which the grains are exported mainly to the US, China and Europe. Waters from the Laranjinha river (the main watercourse in the region that flows into the Paranapanema river) and the Pedras stream (its tributary where the mining effluents used to be discharged) are used for agricultural irrigation.

In the region, the outcropping stratigraphic units belong to the Phanerozoic Paraná Sedimentary Basin and evolved along the South American Platform that spreads in seven states in Brazil as well as in Uruguay, Argentina and Paraguay. The units with Permian age belong to Itararé, Guatá (Rio Bonito and Palermo formations) and Passa Dois (Irati, Sierra Alta and Teresina formations) groups (Shuqair, 2002; Bizzi et al., 2003). The coal deposit is hosted in Rio Bonito Formation and $U$ mineralization has also been observed within Permian coal seams from Rio Bonito Formation, occurring along the interface from the coal-bearing horizon, sandstones and carbonaceous siltstones (Medeiros and Thomaz Filho, 1973).

In the investigated area, the coal horizon thickness varies between 0.50 and $0.65 \mathrm{~m}$ and it is located at a variable depth of 38-75 m (ANEEL, 2011). Chemical analysis (moisture content $=6 \%$, volatile matter $=28.8 \%$, fixed carbon $=32.5 \%$, ash content $=38.7 \%$, sulfur content $=4-12 \%$, calorific value $=4300 \mathrm{kcal} \mathrm{kg}^{-1}$ ) classify the coal as high volatile bituminous (Shuqair, 2002).

Coal is nowadays extracted from an underground mine (named 08), in operation since 2014, although mining activities have occurred since the 1950s and left important impact associated with water and soil quality. The water used for coal washing after its crushing has been recycled in a closed system and physically treated in a pond. Before 2008, the effluent had been discharged into a stream near the mine. This pond also receives the acid effluent generated in the tailing piles. However, the effluents may reach the soil, groundwater and surface water, modifying their chemical composition and contributing to the surface water, groundwater and soil contamination (Galhardi and Bonotto, 2016).

The coal waste was disposed in two main tailing piles: one composed of 'sterile' waste (older than 50 years) that was not protected with waterproofing and $\mathrm{CaO}$ addition to control $\mathrm{pH}$ and another that accumulates material with high pyrite concentration, which has waterproofing and $\mathrm{CaO}$ was added to control $\mathrm{pH}$. The tailing piles are located in an outcrop area of Palermo Formation, composed by clays and siltstones, interbedded with sandy layers 

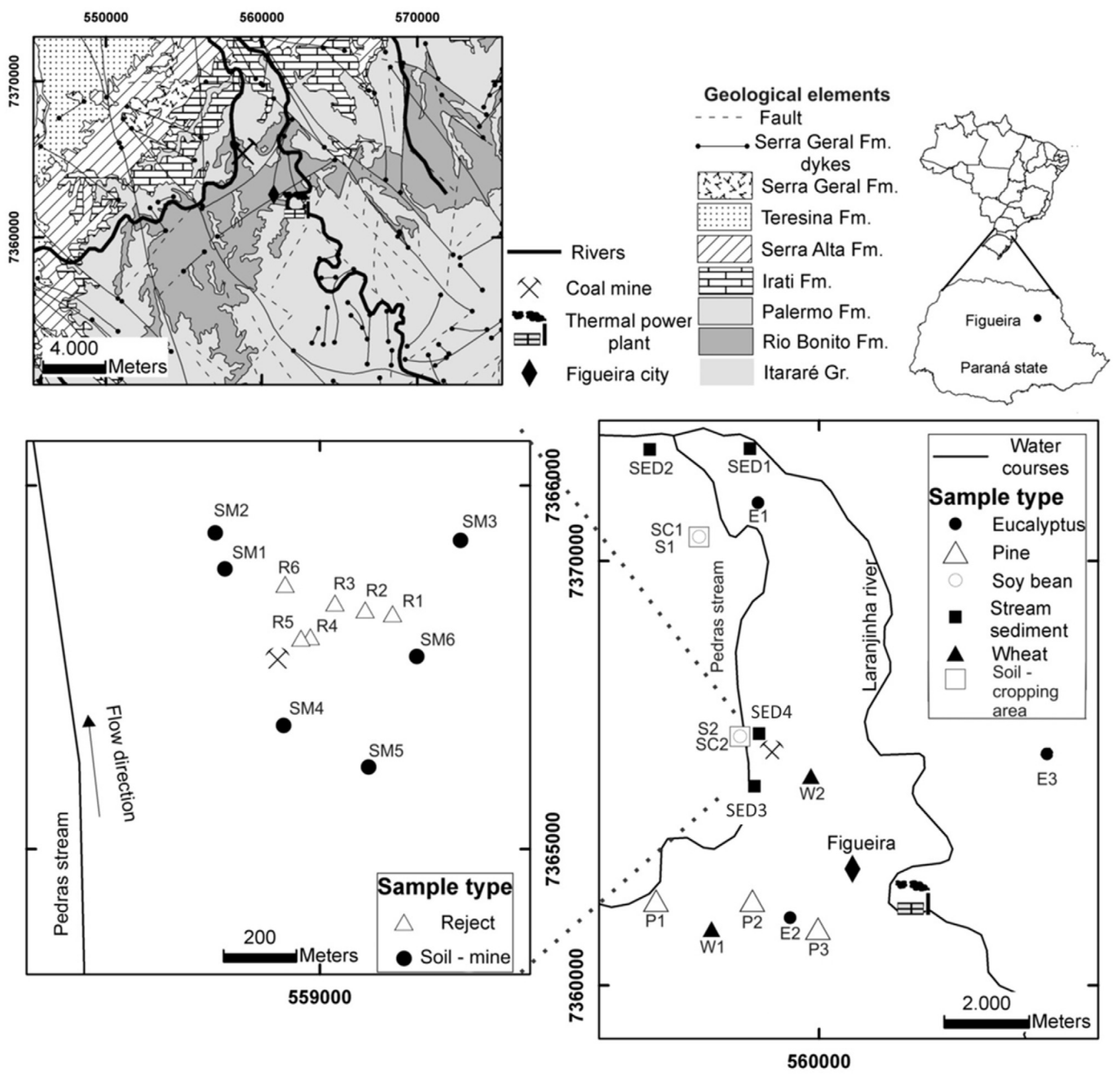

Fig. 1. Location of the study area and sampling points.

(Krebs and Alexandre, 1998). As the basal portion of this geologic unit is composed by sandy material, it is a reasonable groundwater reservoir.

In the thermal power plant, in operation since 1963, the fly ash is collected by emission control systems. Flues et al. (2006) concluded that the coal combustion in the thermal power plant in Figueira city increases the radionuclide concentrations in the atmospheric particulate matter by a factor of 5-10 times, which was corroborated by Campaner at al. (2014) who found high activity concentrations of ${ }^{238} \mathrm{U},{ }^{226} \mathrm{Ra}$ and ${ }^{210} \mathrm{~Pb}$ in coal and its ashes and also in the topsoil of the region.

\subsection{Collection and treatment of the samples}

Soil, sediment, coal ash, coal waste and coal were sampled for chemical characterization. Sample collection was performed in
August/2013 (1.1 mm monthly rainfall) and February/2014 (341.6 mm monthly rainfall) to allow the comparison of the results in different weather conditions. The predominant wind direction in the area is SE-NW. The sampling focused a diameter of $10 \mathrm{~km}$ around the affected area. The following samples were collected (Fig. 1): stream sediments - SED1 (Laranjinha River, upstream the mine), SED2 (Laranjinha river, downstream the mine), SED3 (Pedras stream, upstream the mine), SED4 (Pedras stream, downstream the mine); soil in areas close to mining and thermal power plant - SM1SM6; coal waste from tailing piles - R1-R6; coal from the underground coal mine - C1-C2, and coal ash - A1, A2.

The sediments samples were collected using a PVC pipe ( $1.5 \mathrm{~m}-$ long, $10 \mathrm{~cm}$ diameter), which was introduced into the passive margin of each point and withdrawn when filled about $30 \mathrm{~cm}$ or until a total of about $2 \mathrm{~kg}$ of material was sampled from multiple cores at the same site. The sediments were stored in plastic 
containers. Soil was sampled using a manual collector after the surface was cleaned for vegetation cover removal. Samples $(2 \mathrm{~kg})$ were collected to a depth of $20 \mathrm{~cm}$ (EMBRAPA, 1997; IAEA, 2010) in three points distributed among an area of $10 \mathrm{~m}$-diameter, stored in plastic containers, being previously quartered in field (AlHamarneh et al., 2016). Coal was sampled in the currently active underground cave for coal exploitation. Ashes (the material from bag filters after coal burning in thermal power plant) were sampled directly in the tailing in which they were deposited next to the thermal power plant. Coal and coal ashes were sampled at three different points in the respective outcropping areas and tailing piles before homogenization and quartering. Samples of soil, sediment, coal waste, coal ash and coal were dried at $105{ }^{\circ} \mathrm{C}$ until constant weight and manually homogenized.

Plants and agricultural soils were collected in areas close to the mine in January/2015. Leaves (S1-L, S2-L) and grains (S1-G, S2-G) of soybean (Glycine max), leaves (W1-L, W2-L) and grains (W2-G, W3G) of wheat (Triticum), leaves (E1-L, E2-L, E3-L) and bark (E1-B, E2B, E3-B) of eucalyptus (Eucalyptus sp. - E1; Eucalyptus botryoides Sm. - E2) and leaves (P1-L, P2-L, P3-L) and bark (P1-B, P2-B, P3-B) of pine (Pinus caribaea Morelet) were sampled. The species of trees are not deciduous and the barks and leaves were sampled from mature individuals. Soybean and wheat were sampled during the harvest period, allowing the collection of leaves and mature grains. For each sample a number of at least three individuals were sampled. Cultivated soils (SC1-SC2) were collected next to the cropping areas, following the procedure described above, to allow the calculation of the TF. The radionuclide concentrations in soil used for the TF calculation was the mean value between the SC1 and SC2. Hence, TF data for plant leaves, grains and barks were calculated and contrasted to those reported in literature.

Plant samples were identified at the Botanic Institute of São Paulo, Brazil. In LABIDRO - Isotopes and Hydrochemistry Laboratory, São Paulo State University (UNESP), Rio Claro, São Paulo, Brazil, leaves and bark samples were washed with distilled water several times to remove the residual particulates. All the samples were oven dried at $60{ }^{\circ} \mathrm{C}$ until constant weight, macerated and homogenized, as described by Loppi et al. (2003) and Saiki et al. (2007).

\subsection{Chemical and physical analyses in soils, coal waste and sediment}

Chemical and physical properties of stream sediments, soil and waste samples were measured in LABIDRO (Isotope and Hydrochemistry Laboratory) and LEC (Ceramic Studies Laboratory), at the Department of Petrology and Metallogeny - UNESP, Rio Claro, São Paulo, Brazil. For pH and electrical conductivity (EC) the method described by EMBRAPA (1997) was used. Eh was measured in the lab as described by Bonotto (1996). Cation-exchange capacity (CEC) was determined according to Chen et al. (1974). Organic carbon (OC) content was measured indirectly using the method of oxidation in $1.0 \mathrm{~N} \mathrm{~K}_{2} \mathrm{Cr}_{2} \mathrm{O}_{7}$ in acid medium $\left(\mathrm{H}_{2} \mathrm{SO}_{4}\right)$, according to EMBRAPA (1997).

Granulometric analysis was performed via wet sieving (sand particles) and laser diffraction (clay and silt particles) using a Malvern particle size analyzer (Mastersizer/2000). Using $1 \mathrm{~g}$ of soil, $10 \mathrm{~mL}$ of sodium hexametaphosphate solution (4\%) was added and after at least $24 \mathrm{~h}$ the analysis was done. For identification of the clay minerals, X-ray diffraction was done using a Siemens D5000 diffractometer, as described by Roveri (2010). Clay fraction was obtained by disintegration in distilled water followed by decantation of the fraction greater than $2 \mu \mathrm{m}$ according to the Stokes Law. Three types of scanning were used: in natural conditions, saturated with ethylene glycol (to verify the presence of expansive minerals) and heated to $500{ }^{\circ} \mathrm{C}$ (to observe changes in the kaolinite peak).
2.4. Gamma spectrometry analysis in sediments, coal, coal waste, coal ash and soils from mine

Sediments, soils, coal, coal waste and coal ash from the tailings pile were characterized for the $\mathrm{U}$, Th and $\mathrm{K}$ content by gamma spectrometry in LABIDRO, UNESP, Brazil. In the classical spectrum of gamma rays, $\mathrm{U}$, Th and $\mathrm{K}$ are quantified by the ${ }^{214} \mathrm{Bi},{ }^{208} \mathrm{Tl}$ and ${ }^{40} \mathrm{~K}$ photopeaks, respectively. As a result, the concentrations are expressed in terms of equivalent for $\mathrm{U}(\mathrm{eU})$ and $\mathrm{Th}(\mathrm{eTh})$ and percentage of K (Bristow, 1983).

Sample preparation was based on the method described by Duarte (1997). Approximately $40 \mathrm{~g}$ of the material was wrapped in aluminum flasks properly sealed, where they remained for about 26 days to reach secular radioactive equilibrium in the $U$ and $T h$ decay series. A NaI(Tl) scintillator crystal was used and the system was calibrated by using standards of ${ }^{137} \mathrm{Cs}$ and ${ }^{60} \mathrm{Co}$ pitchblende, monazite sand and KCl (Duarte, 1997; Vergotti, 2008). Maestro II EG\&G-ORTEC software was used to process the data.

\subsection{Extraction by UTEVA resin and alpha spectrometry analysis in} coal, coal waste, coal ash, plants and cultivated soils

Alpha spectrometry was used for measuring the ${ }^{234} \mathrm{U},{ }^{238} \mathrm{U}$, and ${ }^{210}$ Po activity concentration in plants, coal, ash and soil samples at Applied Nuclear Physics Laboratories, University of Seville, Seville, Spain. A fraction of 5-10 g of dry sample was digested in an open system during $40 \mathrm{~h}$ with $80 \mathrm{~mL}$ of $\mathrm{HNO}_{3} 8 \mathrm{M}$ and $20 \mathrm{~mL}$ of $\mathrm{H}_{2} \mathrm{O}_{2}$ added gradually, after adding the tracer solution containing ${ }^{209} \mathrm{Po}-{ }^{228} \mathrm{Th}^{232} \mathrm{U}$. After the acid digestion, the resulting solution was filtered through a cellulose membrane filter with porosity of $45 \mu \mathrm{m}$ and the supernatant was evaporated and re-dissolved in $10 \mathrm{~mL}$ of $\mathrm{HNO}_{3} 3 \mathrm{M}$. The volume of the solution was completed with deionized water to $50 \mathrm{~mL}$ and it was added $2 \mathrm{~mL}$ of an iron carrier solution $\left(\mathrm{Fe}^{3+}\right)$ and ammonia, until it reached a $\mathrm{pH}$ around 8.5 . The samples were centrifuged and $10 \mathrm{~mL}$ of $\mathrm{HNO}_{3} 8 \mathrm{M}$ were added to the precipitate.

Radiochemical separation was used for separating the $U$, Th and Po by using liquid-liquid extraction (Mantero et al., 2010; Lehritani et al., 2012). The method consists of three parts, starting with the Po extraction. Tributyl phosphate (TBP), $10 \mathrm{~mL}$, was added in a separation funnel to the previously prepared solution. The solution was shaken for $10 \mathrm{~min}$ before the extraction. The procedure was repeated three more times using $\mathrm{HNO}_{3} 8 \mathrm{M}$. In this step, Th and $\mathrm{U}$ were retained in the organic phase, whereas Po was transferred to the aqueous phase.

The second step consisted on Th extraction and $20 \mathrm{~mL}$ of xylene plus $15 \mathrm{~mL}$ of $\mathrm{HCl} 1.5 \mathrm{M}$ were added to the separation funnel. The extraction was repeated two times more with $15 \mathrm{~mL}$ of $\mathrm{HCl} 1.5 \mathrm{M}$. Uranium was in the solution containing the mixture of organic compounds, while Th was eluted. For U separation, three extractions were conducted, adding $15 \mathrm{~mL}$ of deionized water into the separation funnel for recovering the $U$ from TBP into the aqueous phase. The solutions containing $U$ and Po were heated to dryness.

For Po autodeposition, about $1 \mathrm{~g}$ of ascorbic acid and $50 \mathrm{~mL}$ of $1.5 \mathrm{M} \mathrm{HCl} 1.5 \mathrm{M}$ were added to the beaker containing a copper disc and the Po isolated after its evaporation. After $2 \mathrm{~h}$ of heating $\left(50-60^{\circ} \mathrm{C}\right.$ ), Po was autodeposited on the copper disc (Díaz-Francés et al., 2013). U-isotopes were electrodeposited in stainless steel discs based on Hallstadius (1984). The procedure consisted of adding $0.5 \mathrm{~g}$ of $\mathrm{H}_{2} \mathrm{SO}_{4}$ (ultrapure), $5 \mathrm{~mL}$ of deionized water and 2 drops of phenolphthalein to the beakers containing the dry residue after evaporation of the $U$ previously extracted. The $\mathrm{pH}$ was converted to the turning point using ammonia vapor. The solution was put into the electroplating cell and the $\mathrm{pH}$ was adjusted to approximately 2.4 by the addition of $1 \% \mathrm{H}_{2} \mathrm{SO}_{4}$. With a platinum 
wire acting as anode, a current of $1.2 \mathrm{~A}$ was applied during $1 \mathrm{~h}$ for the $U$ electrodeposition in the disk.

The alpha emissions were measured through a Canberra system using semiconductor PIPS (Passivated Implanted Planar Silicon) detectors, wherein Po, and $U$ alpha particles were counted in different chambers in order to avoid contamination. The system was calibrated with standards of ${ }^{239} \mathrm{Pu},{ }^{242} \mathrm{Pu}$ and ${ }^{241} \mathrm{Am}$ and the Alpha Analyst program was used for processing the spectra. The mean chemical yields for alpha spectrometry were $41 \%$ in the case of $\mathrm{U}$, and $44 \%$ for Po.

\section{Results}

\subsection{Chemical, physical and gamma spectrometric parameters for sediments, soils and coal waste from mine}

Chemical and physico-chemical data for soils, coal waste and sediments samples are in Table 1. In soils and coal waste collected at the mining area, the silt fraction was predominant, as well as in sediment collected in the wet month.

In the dry month, the average $\mathrm{pH}$ was more acid for coal waste than the soils. In general, the average $\mathrm{pH}$ values for soils and sediments samples were more acidic in the rainy season. Potential redox showed no significant variation between the monitoring periods with exception for soils samples, which was higher in wet month $(439 \pm 32 \mathrm{mV})$ than in dry month $(346 \pm 87 \mathrm{mV})$. The average CEC was higher in the coal waste samples $(34 \pm 12 \mathrm{cmolc}$ $\mathrm{dm}^{3-1}$ and $42 \pm 24 \mathrm{cmolc} \mathrm{dm}^{3-1}$ in dry and wet month, respectively) than in soils. The OC showed no pronounced variation between the two periods for coal waste and sediments. For soil, the average OC content was higher in dry month $(2.5 \pm 2.1)$ than in the wet month $(1.4 \pm 0.5)$.

The average $\mathrm{K}$ and eU concentration did not show a pronounced variation for soils between the monitored periods. For coal waste and sediment, average $\mathrm{K}$ and eU concentrations were higher in dry month and opposite relation was verified in the case of the sediments, in which average $\mathrm{K}$ and eU was lower in the dry month. The eTh average concentration for soils did not ranged significantly between the monitored periods. In the dry month, however, its value for sediment was higher and for coal waste was lower, when compared with the results found for wet month (Table 1 ).

\subsection{Biomonitoring and alpha spectrometry results}

The content in radionuclides measured by alpha spectrometry in cultivated soils (SP1, SP2), coal (C1, C2), coal ash (A1, A2), soybean, wheat, pine and eucalyptus ( $\mathrm{B}=$ bark; $\mathrm{G}=$ grains; $\mathrm{L}=$ leaves) collected in Figueira city are in Table 2 . The TF values are in Table 3.

\section{Discussion}

\subsection{Chemical features of the soils, sediments and coal waste}

The main mineral species found in the clay samples from the soils and sediments sampled in the mining area were montmorillonite, kaolinite, muscovite, gibbsite and jarosite. Pyrite quickly oxidizes in the presence of water and oxygen and was not found in the superficial soil sampled at the studied area. These data are in agreement with Silva et al. (2013) in Santa Catarina State, Brazil, where the main mineral found in stream sediments near a coal mine area were quartz, kaolinite, gypsum, muscovite and microcline.

The use of water during the coal mining and the exposure of the coal waste to the atmosphere create appropriate environments for sulfide oxidation and AMD generation. On the other hand, newly formed minerals may play an important role in the attenuation of toxic element dispersion by fixation. Jarosite, for example, is environmentally important because this mineral can assimilate elements such as $\mathrm{Pb}$ and $\mathrm{Cr}$ within its structure (Simona et al., 2004; Silva et al., 2013). These newly formed minerals, such as jarosite and goethite, may be especially concentrated in the clay size fraction of the sediments (Valente et al., 2015). Other important

Table 1

Chemical data for soils, coal waste and sediments samples.

\begin{tabular}{|c|c|c|c|c|c|c|c|}
\hline & & \multicolumn{3}{|l|}{ August/2013 } & \multicolumn{3}{|c|}{ February/2014 } \\
\hline & & Soil & Coal waste & Sediment & Soil & Coal waste & Sediment \\
\hline \multirow[t]{2}{*}{$\mathrm{pH}\left(\mathrm{H}_{2} \mathrm{O}\right)$} & Range & $2.5-6.6$ & $2.8-4.8$ & $3.5-5.6$ & $2.5-4.5$ & $3.2-4.7$ & $3.1-5.3$ \\
\hline & Mean \pm sd & $4.4 \pm 1.4$ & $3.6 \pm 0.8$ & $4.7 \pm 0.88$ & $3.7 \pm 0.8$ & $3.9 \pm 0.6$ & $4.3 \pm 0.9$ \\
\hline \multirow[t]{2}{*}{$\mathrm{pH}(\mathrm{KCl})$} & Range & $1.8-5.6$ & $1.8-3.2$ & $2.3-4.5$ & $1.6-3.4$ & $2.2-3.4$ & $2.1-4.2$ \\
\hline & Mean \pm sd & $3.3 \pm 1.3$ & $2.6 \pm 0.6$ & $3.5 \pm 0.9$ & $2.8 \pm 0.8$ & $2.8 \pm 0.5$ & $3.2 \pm 0.9$ \\
\hline \multirow[t]{2}{*}{$\mathrm{EC}\left(\mathrm{mS} \mathrm{cm}^{-1}\right)$} & Range & $0.01-2.85$ & $0.34-2.73$ & $0.06-1.32$ & $0.03-2.6$ & $0.04-1.1$ & $0.1-1.9$ \\
\hline & Mean \pm sd & $0.6 \pm 1.1$ & $1.56 \pm 0.8$ & $0.4 \pm 0.6$ & $0.6 \pm 1$ & $0.4 \pm 0.4$ & $0.6 \pm 0.9$ \\
\hline \multirow[t]{2}{*}{ Eh $(\mathrm{mV})$} & Range & $216-491$ & $366-490$ & $341-415$ & $410-494$ & $384-461$ & $330-445$ \\
\hline & Mean \pm sd & $346 \pm 87$ & $417 \pm 42$ & $379 \pm 39$ & $439 \pm 32$ & $425 \pm 27.2$ & $375 \pm 50.9$ \\
\hline \multirow[t]{2}{*}{ CEC (cmolc dm $\left.{ }^{3-1}\right)$} & Range & $15-31$ & $20-54$ & $5-52$ & $10-45$ & $15-85$ & $10-37$ \\
\hline & Mean \pm sd & $23 \pm 5.3$ & $34 \pm 12$ & $24 \pm 20$ & $23 \pm 12$ & $42 \pm 24$ & $25 \pm 11$ \\
\hline \multirow[t]{2}{*}{ OC (\%) } & Range & $0.95-5.9$ & $0.95-1.9$ & $0.45-2.7$ & $0.7-2$ & $1-2.5$ & $0.7-2.4$ \\
\hline & Mean \pm sd & $2.5 \pm 2.1$ & $1.45 \pm 0.4$ & $1.4 \pm 1.1$ & $1.4 \pm 0.5$ & $1.5 \pm 0.6$ & $1.5 \pm 0.9$ \\
\hline \multirow[t]{2}{*}{ Sand (\%) } & Range & $12-48$ & $17-60$ & $11-90$ & $14-38$ & $5-15$ & $8-76$ \\
\hline & Mean \pm sd & $27.3 \pm 15.6$ & $31.6 \pm 15.6$ & $47.1 \pm 33.6$ & $23.4 \pm 4.3$ & $11.8 \pm 4.3$ & $37.8 \pm 32.8$ \\
\hline \multirow[t]{2}{*}{ Silt (\%) } & Range & $16-70$ & $4-66$ & $2-75$ & $32-73$ & $67-79$ & $10-79$ \\
\hline & Mean \pm sd & $50.2 \pm 9.9$ & $47.2 \pm 22.3$ & $39.7 \pm 32.7$ & $59.3 \pm 16.5$ & $72.1 \pm 4.1$ & $47.7 \pm 33.6$ \\
\hline \multirow[t]{2}{*}{ Clay (\%) } & Range & $16-36$ & $17-36$ & $9-20$ & $13-30$ & $12-28$ & $13-20$ \\
\hline & Mean \pm sd & $22.5 \pm 8.0$ & $21.2 \pm 8.3$ & $13.2 \pm 4,7$ & $17.3 \pm 6.6$ & $16.1 \pm 6.0$ & $15.4 \pm 3.1$ \\
\hline \multirow[t]{2}{*}{ K (\%) } & Range & $2.7-17.9$ & $8.2-14.7$ & $3.7-7.8$ & $4.6-23.5$ & $4.8-8.7$ & $5.1-10.3$ \\
\hline & Mean \pm sd & $9.5 \pm 4.9$ & $11 \pm 2.7$ & $5.3 \pm 1.9$ & $9.7 \pm 7.2$ & $6.5 \pm 2.2$ & $8 \pm 2.5$ \\
\hline \multirow[t]{2}{*}{$\mathrm{eU}\left(\mathrm{mg} \mathrm{kg}^{-1}\right)$} & Range & $6.2-146$ & $60.7-139$ & $17.8-43.4$ & $17.2-187.9$ & $25.2-61.2$ & $31.8-73.6$ \\
\hline & Mean \pm sd & $57.3 \pm 53$ & $95.5 \pm 35.3$ & $30.4 \pm 11.1$ & $51.6 \pm 66.9$ & $39.3 \pm 16$ & $46 \pm 19.2$ \\
\hline \multirow[t]{2}{*}{ eTh $\left(\mathrm{mg} \mathrm{kg}^{-1}\right)$} & Range & $45.4-145$ & $1.38-78.61$ & $19.5-1222$ & $65.2-1,41.4$ & $57.9-70.1$ & $34.6-103$ \\
\hline & Mean \pm sd & $85.7 \pm 34.7$ & $44.7 \pm 26$ & $340 \pm 588$ & $87.4 \pm 29.6$ & $63.9 \pm 23.3$ & $58.2 \pm 30.7$ \\
\hline
\end{tabular}

Analytical uncertainties corresponding to $1 \sigma$ standard deviation. 
Table 2

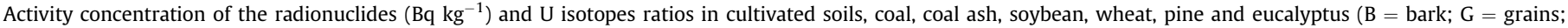
$\mathrm{L}=$ leaves) measured by alpha spectrometry.

\begin{tabular}{|c|c|c|c|c|c|c|}
\hline & & Sample & ${ }^{210} \mathrm{Po}$ & ${ }^{238} U$ & ${ }^{234} U$ & ${ }^{234} U /{ }^{238} U$ \\
\hline Soybean & $\begin{array}{l}\text { Grain } \\
\text { Leave }\end{array}$ & $\begin{array}{l}\text { S1-G } \\
\text { S2-G } \\
\text { S1-L } \\
\text { S2-L }\end{array}$ & $\begin{array}{l}2.96 \pm 0.20 \\
4.0 \pm 0.72 \\
59.2 \pm 2.2 \\
24.8 \pm 1.5\end{array}$ & $\begin{array}{l}0.04 \pm 0.02 \\
0.12 \pm 0.04 \\
0.67 \pm 0.09 \\
0.26 \pm 0.08\end{array}$ & $\begin{array}{l}2.40 \pm 0.29 \\
0.30 \pm 0.08 \\
0.96 \pm 0.12 \\
0.45 \pm 0.11\end{array}$ & $\begin{array}{l}60.0 \pm 14.5 \\
2.50 \pm 2.0 \\
1.43 \pm 1.33 \\
1.73 \pm 1.38\end{array}$ \\
\hline Wheat & $\begin{array}{l}\text { Grain } \\
\text { Leave }\end{array}$ & $\begin{array}{l}\text { W1-G } \\
\text { W2-G } \\
\text { W1-L } \\
\text { W2-L }\end{array}$ & $\begin{array}{l}9.44 \pm 0.54 \\
7.35 \pm 0.39 \\
245 \pm 41 \\
24.8 \pm 1.4\end{array}$ & $\begin{array}{l}0.20 \pm 0.04 \\
0.20 \pm 0.04 \\
5.66 \pm 4.18 \\
0.54 \pm 0.22\end{array}$ & $\begin{array}{l}0.30 \pm 0.05 \\
0.07 \pm 0.01 \\
- \\
2.33 \pm 0.58\end{array}$ & $\begin{array}{l}1.50 \pm 1.25 \\
0.35 \pm 0.25 \\
- \\
4.31 \pm 2.63\end{array}$ \\
\hline Eucalyptus & Bark & $\begin{array}{l}\text { E1-B } \\
\text { E2-B } \\
\text { E3-B } \\
\text { E1-L } \\
\text { E2-L } \\
\text { E3-L }\end{array}$ & $\begin{array}{l}6.80 \pm 0.23 \\
122.4 \pm 9.4 \\
41.6 \pm 3.6 \\
18.1 \pm 1.5 \\
17.9 \pm 1.1 \\
26.8 \pm 1.0\end{array}$ & $\begin{array}{l}0.06 \pm 0.03 \\
0.55 \pm 0.13 \\
0.47 \pm 0.06 \\
0.07 \pm 0.03 \\
6.32 \pm 0.25 \\
25.5 \pm 0.7\end{array}$ & $\begin{array}{l}2.14 \pm 0.32 \\
1.26 \pm 0.22 \\
0.67 \pm 0.07 \\
0.28 \pm 0.07 \\
7.62 \pm 0.29 \\
23.6 \pm 0.6\end{array}$ & $\begin{array}{l}35.6 \pm 10.7 \\
2.29 \pm 1.69 \\
1.43 \pm 1.17 \\
4.0 \pm 2.33 \\
1.21 \pm 1.16 \\
0.93 \pm 0.86\end{array}$ \\
\hline Pine & $\begin{array}{l}\text { Bark } \\
\text { Leave }\end{array}$ & $\begin{array}{l}\text { P1-B } \\
\text { P2-B } \\
\text { P3-B } \\
\text { P1-L } \\
\text { P2-L } \\
\text { P3-L }\end{array}$ & $\begin{array}{l}147 \pm 6 \\
23.4 \pm 0.9 \\
26 \pm 0.8 \\
58.9 \pm 8.1 \\
31.2 \pm 3.5 \\
139 \pm 7\end{array}$ & $\begin{array}{l}1.32 \pm 0.2 \\
1.43 \pm 0.34 \\
0.08 \pm 0.02 \\
8.76 \pm 1.46 \\
2.07 \pm 0.8 \\
0.16 \pm 0.04\end{array}$ & $\begin{array}{l}1.54 \pm 0.22 \\
1.40 \pm 0.34 \\
0.23 \pm 0.03 \\
28.7 \pm 3.3 \\
4.69 \pm 1.36 \\
0.47 \pm 0.07\end{array}$ & $\begin{array}{l}1.17 \pm 1.1 \\
0.98 \pm 1.0 \\
2.88 \pm 1.5 \\
3.28 \pm 2.26 \\
2.27 \pm 1.7 \\
2.94 \pm 1.75\end{array}$ \\
\hline & Soil - cropping area & $\begin{array}{l}\text { SC1 } \\
\text { SC2 }\end{array}$ & $\begin{array}{l}70.1 \pm 3.7 \\
81.7 \pm 4.1\end{array}$ & $\begin{array}{l}22.8 \pm 1.3 \\
40.1 \pm 1.8\end{array}$ & $\begin{array}{l}27.4 \pm 1.4 \\
45.1 \pm 1.9\end{array}$ & $\begin{array}{l}1.20 \pm 1.1 \\
1.12 \pm 1.1\end{array}$ \\
\hline & Coal ash & $\begin{array}{l}\text { A1 } \\
\text { A2 }\end{array}$ & $\begin{array}{l}875 \pm 29 \\
891 \pm 29\end{array}$ & $\begin{array}{l}1.167 \pm 27 \\
651 \pm 20\end{array}$ & $\begin{array}{l}1099 \pm 25 \\
698 \pm 21\end{array}$ & $\begin{array}{l}0.94 \pm 0.93 \\
1.07 \pm 1.05\end{array}$ \\
\hline & Coal & $\begin{array}{l}\mathrm{C} 1 \\
\mathrm{C} 2\end{array}$ & $\begin{array}{l}352 \pm 21.3 \\
235 \pm 8\end{array}$ & $\begin{array}{l}822 \pm 24 \\
224 \pm 6\end{array}$ & $\begin{array}{l}802 \pm 23 \\
182 \pm 5\end{array}$ & $\begin{array}{l}0.98 \pm 0.96 \\
0.81 \pm 0.83\end{array}$ \\
\hline
\end{tabular}

Analytical uncertainties corresponding to $1 \sigma$ standard deviation.

Table 3

Transfer factor values for eucalyptus, pine, soybean and wheat samples ( $\mathrm{B}=$ bark; $\mathrm{G}=$ grains; $\mathrm{L}=$ leaves).

\begin{tabular}{|c|c|c|c|c|c|}
\hline & & Sample & $\mathrm{TF}\left({ }^{210} \mathrm{Po}\right)$ & $\mathrm{TF}\left({ }^{238} \mathrm{U}\right)$ & $\mathrm{TF}\left({ }^{234} \mathrm{U}\right)$ \\
\hline \multirow[t]{6}{*}{ Soybean } & Grain & S1-G & 0.039 & 0.01 & 0.066 \\
\hline & & S2-G & 0.053 & 0.04 & 0.08 \\
\hline & & Mean \pm sd & $0.046 \pm 0.010$ & $0.025 \pm 0.021$ & $0.073 \pm 0.010$ \\
\hline & Leave & S1-L & 0.780 & 0.021 & 0.027 \\
\hline & & S2-L & 0.327 & 0.08 & 0.012 \\
\hline & & Mean \pm sd & $0.554 \pm 0.320$ & $0.051 \pm 0.042$ & $0.020 \pm 0.011$ \\
\hline \multirow[t]{6}{*}{ Wheat } & Grain & W1-G & 0.124 & 0.06 & 0.08 \\
\hline & & W2-G & 0.097 & 0.06 & 0.02 \\
\hline & & Mean \pm sd & $0.111 \pm 0.019$ & $0.06 \pm 0.00$ & $0.05 \pm 0.04$ \\
\hline & Leave & W1-L & 3.223 & 0.180 & - \\
\hline & & W2-L & 0.327 & 0.017 & 0.064 \\
\hline & & Mean \pm sd & $1.755 \pm 2.048$ & $0.099 \pm 0.115$ & - \\
\hline \multirow[t]{8}{*}{ Eucalyptus } & Bark & E1-B & 0.090 & 0.02 & 0.059 \\
\hline & & E2-B & 1.612 & 0.017 & 0.035 \\
\hline & & E3-B & 0.548 & 0.015 & 0.018 \\
\hline & & Mean \pm sd & $0.0750 \pm 0.781$ & $0.017 \pm 0.003$ & $0.037 \pm 0.021$ \\
\hline & Leave & E1-L & 0.238 & 0.02 & 0.008 \\
\hline & & E2-L & 0.236 & 0.201 & 0.210 \\
\hline & & E3-L & 0.353 & 0.811 & 0.653 \\
\hline & & Mean \pm sd & $0.276 \pm 0.067$ & $0.344 \pm 0.414$ & $0.290 \pm 0.330$ \\
\hline \multirow[t]{8}{*}{ Pine } & Bark & P1-B & 1.933 & 0.042 & 0.043 \\
\hline & & P2-B & 0.309 & 0.045 & 0.039 \\
\hline & & P3-B & 0.342 & 0.02 & 0.006 \\
\hline & & Mean \pm sd & $0.861 \pm 0.928$ & $0.036 \pm 0.014$ & $0.029 \pm 0.020$ \\
\hline & Leave & P1-L & 0.776 & 0.279 & 0.792 \\
\hline & & P2-L & 0.411 & 0.066 & 0.129 \\
\hline & & P3-L & 1.831 & 0.05 & 0.013 \\
\hline & & Mean \pm sd & $1.006 \pm 0.737$ & $0.132 \pm 0.128$ & $0.311 \pm 0.420$ \\
\hline
\end{tabular}

Analytical uncertainties corresponding to $1 \sigma$ standard deviation.

minerals are muscovite and microcline that may contribute to the neutralization of acidic wastewater during its weathering, thus, releasing $\mathrm{Al}-\mathrm{Si}$ acids and $\mathrm{K}$ ions into the system (Mello et al., 2014). Coal ash sampled in the tailing piles showed concentrations of $\mathrm{K}$, 
$\mathrm{U}$ and Th of 5, 6 and 7 times higher when compared to the coal samples (Fig. 2). These are in accordance with Flues et al. (2006) and may be a result of loss of organic matter during the combustion of coal.

The $\mathrm{pH}$ and $\mathrm{OC}$ of the sediment sampled downstream of the mine (SED2 and SED4) showed lower values and higher EC values than in upstream (Supplementary material - Table S-1), which may represent the contact of wastes and mining wastes with the superficial waters in the area. However, sediments from Laranjinha river collected upstream the mine showed higher eU and eTh than downstream the mine for both monitoring periods (Table $S-1$ ), indicating that the radioisotopes are naturally present in high concentrations in the studied area. As there are just a few data available, it is not possible to affirm more detailed information about the intensity of the mining activities impacts on sediments and soils in the area. Thus, it would be necessary to do a more extensive sampling in order to evaluate more precisely the effects of coal burning and processing on soil and stream sediments geochemistry and, consequently, possible risks to living organisms.

Some significant correlation $(\alpha=0.05)$ were verified between some parameters. The matrix of Pearson's coefficients for soil and coal waste samples are in Supplementary material (Tables S-2 and $\mathrm{S}-3$ ). For both periods, $\mathrm{pH}$ correlated negatively with EC and for wet month, $\mathrm{pH}$ correlated negatively with clay content. For both periods, EC correlated positively with $\mathrm{K}$ and eU. A possible explanation is the acidification of soils and coal wastes due to the oxidation of sulfide minerals (Galhardi and Bonotto, 2016), which promotes solubilization and increase in the mobility of elements in the environment.

The highest contamination level in the soils occurred close to the dumps. The presence of montmorillonite - a great adsorbent of metals and metalloids - in the coal rejects and soils may be influencing these results and could explain the high amount of $U$ in the samples (Neiva et al., 2016).

The ${ }^{234} U /{ }^{238} U$ values did not change significantly for the analyzed soils $(\mathrm{SC} 1=1.20 \pm 1.1$; SC2 $=1.12 \pm 1.1)$. This fact may be a result of the contribution of the natural geological content of this element in the rocks to the soils from the study area (Boryło and Skwarzec, 2014). The ${ }^{234} \mathrm{U} /{ }^{238} \mathrm{U}$ values for coal $(\mathrm{C} 1=0.98 \pm 0.96$; $\mathrm{C} 2=0.81 \pm 0.83)$ and coal ash $(\mathrm{A} 1=0.94 \pm 0.93 ; \mathrm{A} 2=1.07 \pm 1.05)$ did not ranged pronounced, corroborating for this hypothesis.

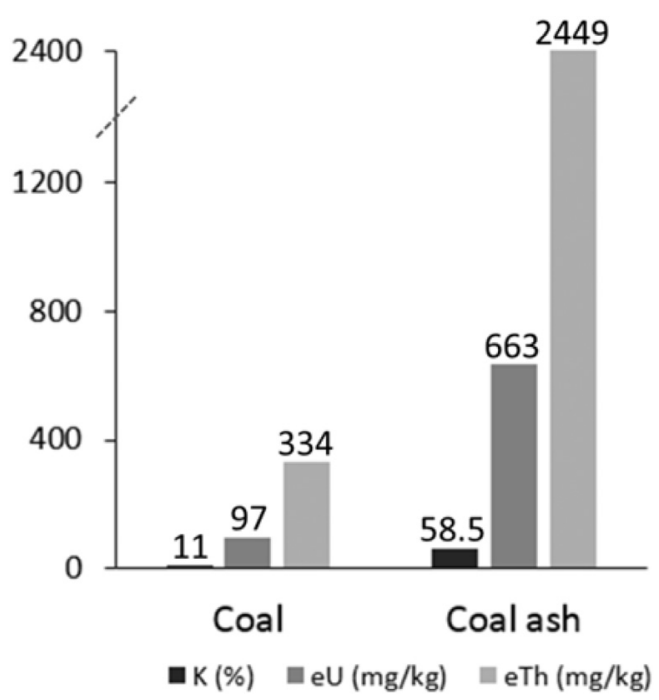

Fig. 2. $\mathrm{K}, \mathrm{eU}$ and eTh content in coal and coal ash measured by gamma spectrometry.

\subsection{Uptake of radionuclides by soybean and wheat}

When comparing grains and leaves of the same sampling point, grains showed lower concentration in radioisotopes than leaves (with exception of S1-G), as noted by Pulhani et al. (2005). This was probably the consequence of the isolation of the grains from radionuclides deposition from the atmosphere.

Soybean and wheat grains showed lower ${ }^{210}$ Po activity concentration than the leaves. Grains of soybean also exhibited lower activity concentrations of ${ }^{238} \mathrm{U}$ and ${ }^{234} \mathrm{U}$ than the leaves, except for ${ }^{234} \mathrm{U}$ in S1-L and S1-G samples. Wheat samples exhibited higher levels of ${ }^{238} U$ and ${ }^{234} U$ in the leaves than in grains. In general, grains of wheat showed higher ${ }^{210}$ Po activity concentrations than grains of soybean, while leaves of wheat showed higher amount of all radionuclides.

Table 3 shows that, in general, grains of wheat showed higher TF for ${ }^{210} \mathrm{Po}$ and ${ }^{238} \mathrm{U}$ than grains of soybean. Leaves of wheat exhibited higher TF for all radioisotopes than leaves of soybean. The ${ }^{210}$ Po TF was greater when compared with the other radionuclides for all sample groups. For ${ }^{210} \mathrm{Po}$, the TF value was comparable with that found by Mazzilli et al. (2012) for sand soils with phosphogypsum application in soybean samples in Brazil. The few reports on the distribution of ${ }^{210} \mathrm{Po}$ and other radionuclides in plants (Tome et al., 2003; Mitchell et al., 2013) makes the comparison between the values reported here limited.

Al-Masri et al. (2008) found lower values of TF for aerial parts of wheat grown in Syria when compared with the average values reported in Table 3. The trend in higher TF values in tropical areas when compared with temperate areas may be due to the climatic conditions that enable higher leaching rate of elements and compounds from rocks/soils (IAEA, 2010), including organic matter, which can increase the bioavailability of the elements in the soils and, consequently, the absorption by vegetables.

The recommended value of TF by IAEA (2010) for U in the case of cereal grains is 0.018 and for leguminous plants is 0.038 . These values have been generally exceeded for both $U$ isotopes ${ }^{238} \mathrm{U}$ and ${ }^{234} \mathrm{U}$ for the plants analyzed (Table 3 ). Radiological assessments for non-human biota are relatively recent. Many of the approaches are still under development (Beresford et al., 2008). According to Mitchell et al. (2013), there is little information about the uptake of $\mathrm{U}$ following deposition onto above-ground plant parts, which can limit the comparison and the understanding about the uptake of radionuclides from anthropic sources by plants.

The TF values must be interpreted cautiously because there is no differentiation between adsorption to the tissue surface and real absorption into the plant, or other mechanisms of radionuclide retention (Favas et al., 2016), specially for the leaves. Variable distribution of $U$ and Po in soils also difficult the interpretation of TF values (Shtangeeva, 2010). The use of TF is based on the assumption that the uptake of elements by plants is linear (Sheppard and Sheppard, 1985), but the linearity may not occur, making difficulties to the measurement of availability of radionuclides to plants from soil, as each plant and soil combination may have a unique curvilinear relationship (Shtangeeva, 2010).

Differences in bioavailability of radionuclides among soils may or may not be based on just quantitative properties of the soils and radionuclide concentrations in plants are not always correlated to soil radionuclide concentrations (Sheppard and Sheppard, 1985; Sheppard and Evenden, 1992; Shtangeeva, 2010; Tuovinen et al., 2011). According to some authors (e.g., Sheppard et al., 2005; Tuovinen et al., 2011; Al-Hamarneh et al., 2016), the relation between concentration of radionuclides in soil/plant tissues and TF values is non-linear. However, the dependency of TF values on the soil concentration should be considered (Sheppard and Sheppard, 1985; Vandenhove et al., 2009). In this paper, with little 
information available, no mechanistic prediction of TF based on soil properties can be made.

Providing information about the TF of radionuclides from soil to edible plants is substantive. Cultivation of organic soil where radionuclides have accumulated for a long period is an important human exposure pathway (Saetre et al., 2013). Data analyzed for phylogenetic effects in element concentrations in plants has focused on concentrations in green shoots (Willey, 2014). For the majority of plant species there are no measurements of TF and less information is provided for radionuclides. Fundamental understanding of the differences in elements accumulation considering the biodiversity, especially for edible vegetables, might be very useful for predicting the fate of radionuclides (Willey, 2014). The radioactive disequilibrium can be an important tool for the prediction of radionuclides dynamic in the natural environment, for both biotic and abiotic components (Boryło and Skwarzec, 2014).

The ${ }^{234} \mathrm{U} /{ }^{238} \mathrm{U}$ ratios for soybean leaves and the soil from the studied area were close, as well as the ashes. Possibly, the contribution to the $U$ in the cultivated soil from the area comes from the ashes that are transported from the thermal power plant and are deposited via wet or dry deposition in the region. Shibahara et al. (2015) found isotopic ratio of $U$ in plant samples close to the natural isotopic abundance, suggesting no significant $U$ contamination. This was not verified in the studied area, where all samples exhibited ratios different of the natural value of ${ }^{234} \mathrm{U} /{ }^{238} \mathrm{U}$ (0.00055). These results indicate the contribution of isotopically altered $U$ to the atmosphere and soils.

The radioactive imbalance based on the ${ }^{234} \mathrm{U} /{ }^{238} \mathrm{U}$ values was more pronounced in the case of soybean and wheat samples that exhibited isotopic ratios ranging from 0.36 to 65.91 (IAEA, 2010). Deviations from the equilibrium between ${ }^{234} U$ and ${ }^{238} U$ in environmental samples are large (Boryło and Skwarzec, 2014). The higher values of ${ }^{234} U /{ }^{238} U$ ratio may be a result of other $U$ sources (e.g., fertilizers, spring waters, dust and sediments; Skwarzec et al. (2002)) in addition to soils and mining effluents. For example, Pulhani et al. (2005) found that fertilizer application and soil nutrient content can affect the absorption of radionuclides by plants (Pulhani et al., 2005). Furthermore, errors while preparing and analyzing the material and related to methodologies of plant sampling and preparation cannot be excluded (Shtangeeva, 2010).

\subsection{Uptake of radionuclides by pine tree and eucalyptus species from the soil}

Differences were observed in the TFs of Po and U among plant species (Skoko et al., 2017). With exception of ${ }^{234} U$, radioisotopes showed higher mean concentration in barks of pine than of eucalyptus. Leaves of pine showed higher mean concentration of radioisotopes than leaves of eucalyptus, excepting ${ }^{238} \mathrm{U}$. Table 2 shows that, with exception of ${ }^{210} \mathrm{Po}$ (P1-L), radioisotopes showed lower concentrations in barks than in leaves of pine.

The mean TF was higher for the leaves of both species in the case of ${ }^{238} \mathrm{U}$ and ${ }^{234} \mathrm{U}$. The ${ }^{210}$ Po exhibited higher activity concentrations in the pine leaves than in the eucalyptus leaves. The TF for ${ }^{210} \mathrm{Po}$ reached the highest values for all samples when compared to other radionuclides (Fig. 3). The foliar deposition in the above-ground parts of plants, in some cases, is responsible for the high contamination levels of ${ }^{210} \mathrm{Po}$ in the foliage (Mitchell et al., 2013).

Higher TFs for the radionuclides were found in the leaves than in barks for pines. This is comparable to the findings of Strok et al. (2011). According to the authors, this allocation pattern is expected once in leaves the need for nutrients is higher, although the transpiration rate and metal accumulation can be regulated by the plants, is species specific and can also be affected by environmental factors (Štrok et al., 2011). For example, a major contributing pathway to radionuclides absorption by vegetables is atmospheric deposition, which is little investigated when evaluating the root uptake of elements (Mitchell et al., 2013).

On the other hand, an opposite relation was verified in the case of the eucalyptus, i.e., the mean value for the TF in the case of ${ }^{210} \mathrm{Po}$ was higher in the bark than in the leaves. The lower mean TF in leaves than in bark, which is not affected by atmospheric ${ }^{210} \mathrm{~Pb}$ deposition, indicates that this cannot be explained only by the atmospheric deposition effect.

The maximum uptake of ${ }^{238} \mathrm{U}$ and ${ }^{234} \mathrm{U}$ isotopes has also been observed for the leaves than in the bark samples for both species. For pine sampled in an area close to a U tailing pile in Slovenia, Strok et al. (2011) found lower geometric means of radionuclides for woods and foliage than those found in Figueira city. The TF values for ${ }^{238} \mathrm{U}$ reported by Petrova (2006) in pine leaves (range of 0.004-0.0159) were slightly higher than the values found at the studied area, which are between 0.066 and 0.279 (Table 3).

SC2 was sampled closely to the coal mine but its ${ }^{234} \mathrm{U} /{ }^{238} \mathrm{U}$ ratio $(1.12 \pm 1.1)$ showed no significant differences between SC1 $(1.20 \pm 1.1)$, located distant from the mine but disposed in the preferred wind direction (SE-NW). On the other hand, S1-G, E1-B and $\mathrm{WL}-2$, located in the wind preferred direction, exhibited the highest TFs values $(60.0 \pm 14.5,35.6 \pm 10.7$ and $4.31 \pm 2.63$, respectively), possible indicating a radioactive imbalance due to the higher deposition of radionuclides.

Fig. 3 exhibits the mean TFs for the group of plants analyzed. When comparing the plant species analyzed in this paper, leaves of pine showed the highest TF value for ${ }^{234} U(0.311 \pm 0.420)$, while leaves of eucalyptus showed the highest $T F$ value for ${ }^{238} \mathrm{U}$ $(0.344 \pm 0.414)$. These trees are cultivated in the area for production of wood and cellulose, indicating that a better evaluation of the translocation and transfer factors of radionuclides to bark and leaves should be better investigated in order to provide a more accurate understanding about possible exposure routes to humans. Similar results were found by Favas et al. (2016) for terrestrial species that could be used as diagnostic tools for monitoring $U$ environmental pollution in a mining area, as they accumulate more $U$ near the mine. Therefore, the authors alert that the use of the biomasses from the surrounding should be restricted so these plants could potentially be used to control $U$ contamination in abiotic matrices reducing risks of its transfer to higher tropic levels.

Predicting soil-to-plant transfer is important to assess radionuclide bioavailability in terrestrial ecosystems. Soil properties and natural difference in the ability of plants to assimilate radionuclides may be one of the reasons why concentrations of radionuclides differ significantly in various plant species in this paper. Availability of radionuclides contributes to the degree of their transfer to plants but other factors could help understanding potential risks related to levels of radioactive elements in soils, from molecular to individuals and ecological scale. In general, these biological factors are less well understood than the factors controlling availability from soil and could bring us a better understanding about the transfer of radionuclides from soil to plants and processes involved (Willey, 2014). However, only complex models considering soil characteristics could help to predict $U$ and Po uptake, as TF is not related to simple bioavailability parameters (Vandenhove et al., 2009).

\section{Conclusions}

The results presented here give information regarding the 


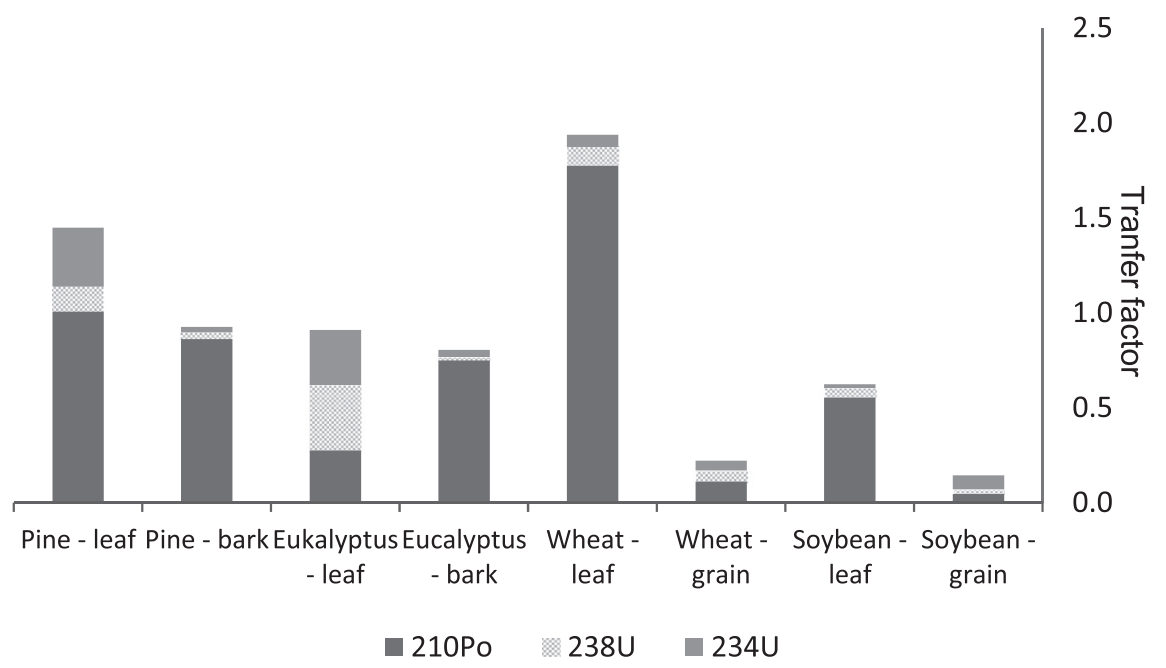

Fig. 3. Mean values for TFs for radionuclides by group of plant.

availability of radionuclides that are present in agricultural soils from areas closely to a coal mine and coal-fired power plant, giving us in turn an indication of the potential for radionuclides uptake by crops growing in soils affected by coal mining and burning and pointing out the need of safety assessments in these areas.

Coal mining can affect soil quality in the investigated area in southern Brazil, where the AMD and other environmental factors are responsible for the leaching of $U$ from the tailing piles to the soils in the area, much of them used for cropping. The samples of coal ash generated in the coal-fired power plant presented concentrations of $\mathrm{K}, \mathrm{U}$ and Th enriched in 5, 6 and 7 times, respectively, when compared to the coal, representing another source of radionuclides for surface soils, which was corroborated by the values of ${ }^{234} \mathrm{U} /{ }^{238} \mathrm{U}$.

Higher ${ }^{210}$ Po activity concentrations were found in the foliage of the pines than in the bark samples, which could be explained by the contribution of atmospheric deposition of ${ }^{210} \mathrm{Po}$ on the trees. Eucalyptus and pine trees can be used as biomonitors of the soil pollution in the area, giving information about environmental aspects related to the impact of mining activities on the natural soils. The leaves of wheat and soybean exhibited higher transfer factors for ${ }^{210} \mathrm{Po}$ and ${ }^{238} \mathrm{U}$ than the respective grains. In some cases, the TF exceeded those proposed by IAEA (2010), which in association with the high amounts of $\mathrm{U}$, Th and $\mathrm{K}$ found in the soils sampled in areas affected by the coal mining can indicate that the mining activities represent considerable environmental risks in the investigated area.

Based on the radioactive imbalance found for some plants, the influence of other sources of radionuclides should be better investigated in the area in order to provide an accurate understanding about the natural and anthropogenic sources of these elements for soils. Deviations from the natural U isotopic ratios were recorded at all investigated areas for all the groups of samples, which indicate possible industrial and mining sources of $U$ for the plants. A safety assessment of a good representation of transport routes and accumulation of radionuclides in soils with a potential for cultivation is important, mainly in areas contaminated with solid waste and effluents from coal mining and industry. As a recommendation to better understand and control the contamination associated with radionuclides, it is suggested a deeper investigation about the factors that affect the absorption of radioactive elements by plants in tropical areas, particularly in those where the soils used for agricultural activities is affected by industrial and mining sources.

\section{Acknowledgments}

CNPq (National Council for Scientific and Technological Development) in Brazil is thanked by the financial support of the PhD scholarship to JAG (Processes No. 203716/2014-0 and 168677/20148 ). We thank three anonymous referees for helpful comments that improved the readability of the manuscript.

\section{Appendix A. Supplementary data}

Supplementary data related to this article can be found at http:// dx.doi.org/10.1016/j.jenvrad.2017.06.001.

\section{References}

Al-Hamarneh, I., Alkhomashi, N., Almasoud, F.I., 2016. Study on the radioactivity and soil-to-plant transfer factor of 226Ra, 234U and 238U radionuclides in irrigated farms from the northwestern Saudi Arabia. J. Environ. Radioact. 160, 1-7. http:// dx.doi.org/10.1016/j.jenvrad.2016.04.012 0265-931X.

Al-Masri, M.S., Al-Akel, B., Nashawani, A., Amin, Y., Khalifa, K.H., Al-Ain, F., 2008 Transfer of 40K, 238U, 210Pb, and 210Po from soil to plant in various locations in south of Syria. J. Environ. Radioact. 99, 322-331.

ANEEL (Agência Nacional de Energia Elétrica), 2011. A Situação da Produção de Carvão Mineral no Estado do Paraná em Relação a Nota Técnica 034/2011. Tech. Rep. ANEEL, Brasília.

Arbuzov, S.I., Maslov, S.G., Volostnov, A.V., Arkhipov, V.S., 2012. Modes of occurrence of uranium and thorium in coals and peat of northern asia. Solid Fuel Chem. 46, 52-66. http://dx.doi.org/10.3103/S0361521912010028.

Baik, M.H., Hyun, S.P., Hahn, P.S., 2003. Surface and bulk sorption of uranium (VI) onto granite rock. J. Radioanal. Nucl. Chem. 256, 11-18. http://dx.doi.org/ 10.1023/A:1023331521718.

Baxter, M.S., 1993. Environmental radioactivity: a perspective on industrial contributions. IAEA Bull. 35 (2), 33-38.

Beresford, N.A., Balonov, M., Beaugelin-Seiller, K., Brown, J.B., Copplestone, D., Hingston, J.L., Horyna, J., Hosseini, A., Howard, B.J., Kamboj, S., Nedveckaite, T., Olyslaegers, G., Sazykina, T., Batlle, J.V., Yankovich, T.L., Yu, C., 2008. An international comparison of models and approaches for the estimation of the radiological exposure of non-human biota. Appl. Radiat. Isot. 66, 1745-1749. http://dx.doi.org/10.1016/j.apradiso.2008.04.009.

Berghorn, G.H., Hunzeker, G.R., 2001. Passive treatment alternatives for remediating abandoned mine drainage. Remediat. J. 11, 111-127. http://dx.doi.org/10.1002/ rem.1007.

Bizzi, L.A., Schobbenhaus, C., Vidotti, R.M., Gonçalves, J.H., 2003. Geologia, Tectônica e Recursos Minerais do Brasil: texto, mapas e SIG CPRM, Brasília.

Bonotto, D.M., 1996. Comportamento hidrogeoquímico do $222 \mathrm{Rn}$ e isótopos de urânio 238U e $234 \mathrm{U}$ sob condições controladas de laboratório e em sistemas naturais. Post PhD Thesis. UNESP, Rio Claro.

Boryło, A., Skwarzec, B., 2014. Activity disequilibrium between 234U and 238U isotopes in natural environment. J. Radioanal. Nucl. Chem. 300, 719-727. http:// dx.doi.org/10.1007/s10967-014-3001-9. 
Bristow, Q., 1983. Airborne gamma-ray spectrometry in uranium exploration. Principles and current practice. Int. J. Appl. Radiat. Isot. 34 (1), 199-229.

Campaner, V.P., Luiz-Silva, W., Machado, W., 2014. Geochemistry of acid mine drainage from a coal mining area and processes controlling metal attenuation in stream waters, southern Brazil. An. Acad. Bras. Ciênc 86, 539-554. http:// dx.doi.org/10.1590/0001-37652014113712.

Chen, T.J., Santos, P.S., Ferreira, H.C., Zandonadi, A.R., Calil, S.F., Campos, L.V., 1974. Determinação da Capacidade de Troca de Cátions e da Área Específica de Algumas Argilas e Caulins Cerâmicos Brasileiros Pelo Azul de Metileno e Sua Correlação com Algumas Propriedades Tecnológicas. Cerâmica 79, 305-327.

Díaz-Francés, I., Mantero, J., Manjón, G., Díaz, J., García-Tenorio, R., 2013. 210Po and $238 \mathrm{U}$ isotope concentrations in commercial bottled mineral water samples in Spain and their dose contribution. Radiat. Prot. Dosim. 156 (3), 336-342. http:// dx.doi.org/10.1093/rpd/nct075.

Duarte, C.R., 1997. Relações radiométricas e isotópicas na área do Projeto Rio Preto (GO), 119 f. Master thesis. UNESP, Rio Claro.

Empresa Brasileira de Pesquisa Agropecuária (EMBRAPA), 1997. Manual de métodos de análises de solo, 2.ed. Ministério da Agricultura e do Abastecimento, Rio de Janeiro. 1997. 212pp.

Favas, P.J.C., Pratas, J., Mitra, S., Sarkar, S.K., Venkatachalam, P., 2016. Biogeochemistry of uranium in the soil-plant and water-plant systems in an old uranium mine. Sci. Total Environ. 568, 350-368. http://dx.doi.org/10.1016/j.scitotenv. 2016.06.024.

Fernandes, H.M., Pires Do Rio, M.A., Veiga, L.H.S., Amaral, E.C.S., 1997. Environmental radiological problems associated to non-uranium mining and milling industries. In: $4^{\circ}$ Encontro Brasileiro sobre Aplicações Nucleares, Poços de Caldas, 1997.

Flues, M., Camargo, I.M.C., Silva, P.S.C., Mazzilli, B.P., 2006. Radioactivity of coal and ashes from Figueira coal power plant in Brazil. J. Radioanal. Nucl. Chem. 270 (3), 597-602. http://dx.doi.org/10.1007/s10967-006-0467-0.

Food And Agriculture Organization Of The United Nations (FAO), 2012. Food Agric. Commod. Prod, 2012.

Fungaro, D.A., Izidoro, J.C., 2006. Remediação da drenagem ácida de mina usando zeólitas sintetizadas a partir de cinzas leves de carvão. Quim. Nova 29, 735-740. http://dx.doi.org/10.1590/S0100-40422006000400019.

Galhardi, J.A., Bonotto, D.M., 2016. Hydrogeochemical features of surface water and groundwater contaminated with acid mine drainage (AMD) in coal mining areas: a case study in southern Brazil. Environ. Sci. Pollut. Res. 23, 18911-18927. http://dx.doi.org/10.1007/s11356-016-7077-3.

Giblin, A.M., Batts, B.D., Swaine, D.J., 1981. Laboratory simulation studies of uranium mobility in natural waters. Geochim. Cosmochim. Acta 45, 699-709. http:// dx.doi.org/10.1016/0016-7037(81)90043-0.

Gupta, D.K., Chatterjee, S., Datta, S., Veer, V., Walther, C., 2014. Role of phosphate fertilizers in heavy metal uptake and detoxification of toxic metals. Chemosphere 108, 134-144.

Hallstadius, L., 1984. A method for the electrodeposition of actinides. Nucl. Instrum. Methods A 223, 266-267. http://dx.doi.org/10.1016/0167-5087(84)90659-8.

International Atomic Energy Agency (IAEA), 2010. Handbook of Parameter Values for the Prediction of Radionuclide Transfer in Terrestrial and Freshwater Environments. IAEA, Vienna, 2010.194 pp.

Krebs, A.S.J., Alexandre, N.Z., 1998. Situação atual dos recursos hídricos da bacia carbonífera, face às atividades de lavra, beneficiamento e uso do carvão mineral e de outras atividades antrópicas. In: Proceedings of IX Congresso Brasileiro de Águas Subterrâneas, Bahia, pp. 60-65.

Langmuir, D., 1978. Uranium solution-mineral equilibria at low temperatures with applications to sedimentary ore deposits. Geochim. Cosmochim. Acta 42, 547-569. http://dx.doi.org/10.1016/0016-7037(78)90001-7.

Lauria, C.D., Sachi, I.A., Pereira, J.C., Zeharo, R., 1994. Determination of Cesium-137 soil-to-plant concentration ratios for vegetables in Goiania city, Brazil. J. Radioanal. Nucl. Chem. 182 (1), 91-96.

Lehritani, M., Mantero, J., Casacuberta, N., Masqué, P., García-Tenorio, R., 2012. Comparison of two sequential separation methods for $U$ and Th determination in environmental samples by alpha-particle spectrometry. Radiochim. Acta 100 (7), 431-438. http://dx.doi.org/10.1524/ract.2012.1933.

Loppi, S., Riccobono, F., Zhang, Z.H., Savic, S., Ivanovd, D., Pirintsose, S.A., 2003. Lichens as biomonitors of uranium in the Balkan area. Environ. Pollut. 125, 277-280.

Mantero, J., Lehritane, M., Hurtado, S., García-Tenorio, R., 2010. Radioanalytical determination of actinides in refractory matrices by alkali fusion. J. Radioanal. Nucl. Chem. 286, 557-563. http://dx.doi.org/10.1007/s10967-010-0782-3.

Mazzilli, B.P., Saueia, C.H.R., Jacomino, V.M.F., Mello, J.W.V., 2012. Natural radionuclides and metals intake into soya, corn and lettuce grown on soil amended with phosphogipsita. Int. J. Environ. Anal. Chem. 92, 1574-1586.

Medeiros, R.A., Thomaz Filho, A., 1973. Fácies e ambientes deposicionais da Formação Rio Bonito. In: XXVII Congresso Brasileiro de Geologia, São Paulo, vol. 3, pp. 3-12.

Mello, J.W.V., Duarte, H.A., Ladeira, A.C.Q., 2014. Origem e Controle do Fenômeno Drenagem Ácida de Mina. Cad. Temáticos Quím. Nova Esc. 8, 24-29.

Minerais Do Paraná (MINEROPAR), 2001. Diagnóstico preliminar dos impactos ambientais da mineração no Paraná. Curitiba, 207 pp.

Mitchell, N., Pérez-Sánchez, D., Thorne, M.C.J., 2013. A review of the behaviour of U238 series radionuclides in soils and plants. Radiol. Prot. 33, R17-R48. http:// dx.doi.org/10.1088/0952-4746/33/2/R17.

Mkandawire, M., 2013. Biogeochemical behaviour and bioremediation of uranium in waters of abandoned mines. Environ. Sci. Pollut. Res. 20, 7740-7767. http:// dx.doi.org/10.1007/s11356-013-1486-3.

Morrone, N., Daemon, R.F., 1985. Jazida de Urânio de Figueira, Paraná. In: Principais Depósitos Minerais Do Brasil: Recursos Minerais Energéticos. Departamento Nacional de Produção Mineral, Brasília, pp. 133-142.

Neiva, A.M.R., Antunes, I.M.H.R., Carvalhoa, P.C.S., Santos, A.C.T., 2016. Uranium and arsenic contamination in the former Mondego Sul uranium mine area, Central Portugal. J. Geochem. Explor. 162, 1-15.

Papp, Z., Dezso, Z., Daróczy, 2002. Significant radioactive contamination of soil around a coal-fired thermal power plant. J. Environ. Radioact. 59, 191-205. http://dx.doi.org/10.1016/S0265-931X(01)00071-6.

Petrova, R., 2006. Accumulation of natural radionuclides in wooden and grass vegetation from abandoned uranium mines. Opportunities for phytoremediation. In: Merkel, B.J., Hasche-Berger, A. (Eds.), Uranium in the Environment, Mining Impact and Consequences. Springer, Berlin, pp. 507-518.

Planinsek, E., Smodis, B., Benedik, L., 2016. Simultaneous determination and uptake assessment of selected radionuclides in plants grown in substrate contaminated with U-mill tailings. J. Radioanal. Nucl. Chem. 309, 351-365. http://dx.doi.org/ 10.1007/s10967-016-4881-7.

Prikryl, J.D., Jain, A., Turner, D.R., Pabalan, R.T., 2001. Uranium(VI) sorption behavior on silicate mineral mixtures. J. Contam. Hydrol. 47, 241-253. http://dx.doi.org 10.1016/S0169-7722(00)00153-4.

Pulhani, V.A., Dafauti, S., Hegde, A.G., Sharma, R.M., 2005. Mishrau.C.Uptake and distribution of natural radioactivity in wheat plants from soil. J. Environ. Radioact. 79, 331-346.

Roveri, C.D., 2010. Petrologia aplicada da formação Corumbataí (região de Rio Claro SP) e produtos cerâmicos. PhD Thesis. UNESP, Rio Claro,

Saetre, P., Valentin, J., Lagera, P., Avila, R., Kautsky, U., 2013. Land use and food intake of future inhabitants: outlining a representative individual of the most exposed group for dose assessment. AMBIO 42, 488-496. http://dx.doi.org/10.1007/ 13280-013-0400-7.

Saiki, M., Alves, E.R., Marcelli, M.P., 2007. Analysis of lichen species for atmospheric pollution biomonitoring in the Santo André Municipaty. J. Radioanal. Nucl. Chem. 3, 543-547.

Santos, E.E., Lauria, D.C., Amaral, E.C.S., Rochedo, E.R., 2002. Daily ingestion of 232Th, 238U, 226Ra, 228Ra and 210Pb in vegetables by inhabitants of Rio de Janeiro City. J. Environ. Radioact. 62, 75-86.

Santos, P.L., Gouvea, R.C., Dutra, I.R., 1993. Lead-210 in vegetables and soils from an area of high natural radioactivity in Brazil. Sci. Total Environ. 138, 37-46.

Sheppard, M.I., Sheppard, S.C., 1985. The plant concentration concept as applied to natural uranium. Health Phys. 48, 494-500.

Sheppard, S.C., Evenden, W.G., 1992. Bioavailability indices for uranium: effect of concentration in eleven soils. Arch. Environ. Contam. Toxicol. 23, 117-124.

Sheppard, S.C., Sheppard, M.I., Ilin, M., Thompson, P., 2005. Soil-to-plant transfers of uranium series radionuclides in natural and contaminated settings. Radioprotection 40, S253-S259.

Shibahara, Y., Kubota, T., Fujii, T., Fukutani, S., Ohta, T., Takamiya, K., Okumura, R., Mizuno, S., Yamana, H., 2015. 235U/238U Isotopic ratio in plant samples from Fukushima Prefecture. J. Radioanal. Nucl. Chem. 303, 1421-1424. http:// dx.doi.org/10.1007/s10967-014-3542-y.

Shtangeeva, I., 2010. Uptake of uranium and thorium by native and cultivated plants. J. Environ. Radioact. 101, 458-463.

Shuqair, M.S.S., 2002. Estudo da contaminação do solo e água subterrânea por elementos tóxicos originados dos rejeitos das minas de carvão de Figueira no Estado do Paraná. PhD Thesis. Universidade de São Paulo, São Paulo.

Silva, L.F.O., Vallejuelo, S.F.O., Martinez-Arkarazo, I., Castro, K., Oliveira, M.L.S., Sampaio, C.H., Brum, I.A.S., Leão, F.B., Taffarel, S.R., Madariaga, J.M., 2013. Study of environmental pollution and mineralogical characterization of sediment rivers from Brazilian coal mining acid drainage. Sci. Total Environ. 447, 169-178. http://dx.doi.org/10.1016/j.scitotenv.2012.12.013.

Simona, R., Andreas, B., Stefan, P., 2004. Formation and stability of schwertmannite in acidic mining lakes. Geochim. Cosmochim. Acta 68, 1185-1197. http:// dx.doi.org/10.1016/j.gca.2003.07.015.

Skoko, B., Marovic, G., Babic, D., Sostaric, M., Jukic, M., 2017. Plant uptake of $238 \mathrm{U}$ 235U, 232Th, 226Ra, 210Pb and 40K from a coal ash and slag disposal site and control soil under field conditions: a preliminary study. J. Environ. Radioact. 172, 113-121. http://dx.doi.org/10.1016/j.jenvrad.2017.03.011.

Skwarzec, B., Boryło, A., Struminska, A., 2002. $234 \mathrm{U}$ and 238U isotopes in water and sediments of the southern Baltic. J. Environ. Radioact. 61, 345-363. http:/ dx.doi.org/10.1016/S0265-931X(01)00144-8.

Sohlenius, G., Saetre, P., Norden, S., Grolander, S., Sheppard, S., 2013. Inferences about radionuclide mobility in soils based on the solid/liquid partition coefficients and soil properties. AMBIO 42, 414-424. http://dx.doi.org/10.1007/ 13280-013-0408-4.

Štrok, M., Smodiš, B., Eler, K., 2011. Natural radionuclides in trees grown on a uranium mill tailings waste pile. Environ. Sci. Pollut. Res. 18, 819-826.

Tome, F.V., Rodriguez, M.P.B., Lozano, J.C., 2003. Soil-to-plant transfer factors for natural radionuclides and stable elements in a Mediterranean area. J. Environ. Radioact. 65, 161-175. http://dx.doi.org/10.1016/S0265-931X(02)00094-2.

Tuovinen, T.S., Roivainen, P., Makkonen, S., Kolehmainen, M., Holopainen, T., Juutilainen, J., 2011. Soil-to-plant transfer of elements is not linear: results for five elements relevant to radioactive waste in five boreal forest species. Sci. Total Environ. 410-411, 191-197. http://dx.doi.org/10.1016 j.scitotenv.2011.09.043.

UNSCEAR (United Nations Scientific Committee on the Effects of Atomic Radiations), 2010. Sources and Effects of Ionizing Radiations, 2010. UNSCEAR, New 
York. http://www.unscear.org.

USEPA (United States Environmental Protection Agency), 1995. Human Health and Environmental Damages from Mining and Mineral Processing Wastes. Archive document. Office of Solid Waste. US Environ. Protection Agency.

Valente, A., Grandeb, J.A., de la Torre, M.L., Gomes, P., Santistebanb, M., Borregob, J., Sequeira Braga, M.A., 2015. Mineralogy and geochemistry of a clogged mining reservoir affected by historical acid mine drainage in an abandoned mining area. J. Geochem. Explor. 157, 66-76.

Vandenhove, H., Olyslaegers, G. Sanzharova, N., Shubina, O., Reed, E., Shang Z. Velasco, H., 2009. Proposal for new best estimates of the soil-to-plant transfer factor of U, Th, Ra, Pb and Po. J. Environ. Radioact. 100, 721-732.
Vasconcellos, L.M.H., Amaral, E.C.S., Vianna, M.E., Franca, E.P., 1987. Uptake of 226Ra and $210 \mathrm{~Pb}$ by food crops cultivated in a region of high natural radioactivity in Brazil. J. Enviro. Radioact. 5, 287-302.

Vergotti, M., 2008. Uso do 210Pb no estudo da deposição de mercúrio em lagos da bacia do rio Madeira (RO), 126 fl. PhD Thesis. UNESP, Rio Claro.

Willey, N.J., 2014. Soil to plant transfer of radionuclides: predicting the fate of multiple radioisotopes in plants. J. Environ. Radioact. 133, 31-34. http://dx.doi. org/10.1016/j.jenvrad.2013.07.023.

Zhao, C.M., Campbell, P.G.C., Wilkinson, K.J., 2016. 2016. When are metal complexes bioavailable? Environ. Chem. 13, 425-433. 